\title{
Preparation and Characterization of Composite Microporous Gel Polymer Electrolytes Containing $\mathrm{SiO}_{2}\left(\mathrm{Li}^{+}\right)$
}

\author{
Wei-li Li $\cdot$ Ji-jun Tang $\cdot$ Bin-tong Li
}

Received: 29 January 2013 / Accepted: 4 March 2013/Published online: 20 March 2013

(c) The Author(s) 2013. This article is published with open access at Springerlink.com

\begin{abstract}
In this paper, the single ionic conductor $\mathrm{SiO}_{2}\left(\mathrm{Li}^{+}\right)$was first synthesized from Tetraethylorthosilicate and $\gamma$-(2,3-epoxypropoxy) propyltrimethoxysilane (KH560) by sol-gel hydrolysis and then neutralized by lithium hydroxide in methanol. The poly(vinylidene fluoride) based composite microporous gel polymer electrolytes (CMGPEs) doped with $\mathrm{SiO}_{2}\left(\mathrm{Li}^{+}\right)$was prepared by phase inversion method and the desirable CMGPEs was obtained after being activated in liquid electrolyte. The physicochemical properties of the CMGPEs were characterized by FT-IR, DSC, XRD, TG, stress-strain response and electrochemical measurements. It was found that with the addition of $\mathrm{SiO}_{2}\left(\mathrm{Li}^{+}\right)$, the degree of crystallization of microporous polymer membrane was decreased while its porosity increased, which could promote the absorption and gelation of liquid electrolyte. In addition, due to vast amount of $\mathrm{Li}^{+}$ions in the $\mathrm{SiO}_{2}\left(\mathrm{Li}^{+}\right)$, it would promote ionic conductivity at room temperature for the CMGPEs. When the content of $\mathrm{SiO}_{2}\left(\mathrm{Li}^{+}\right)$reached $5 \%$ wt, the ionic conductivity of the CMGPEs could reach $10^{-2} \mathrm{~S} / \mathrm{cm}$ order of magnitude at room temperature and the reciprocal temperature dependence of ionic conductivity of as-prepared CMGPEs follow arrhenius equation, in addition, its electrochemical stability window could reach $5.2 \mathrm{~V}$.
\end{abstract}

Keywords Sol-gel · Phase inversion - PVDF . $\mathrm{SiO}_{2}\left(\mathrm{Li}^{+}\right) \cdot$ Ionic conductivity

The submission is intended for the 2nd international congress on advance materials

W. Li $(\bowtie) \cdot$ J. Tang $\cdot$ B. Li

College of Materials and Engineering, Jiangsu University of

Science and Technology, Zhenjiang 212003, China

e-mail: zjuliweili@163.com

\section{Introduction}

Many types of ionic conducting polymers, generally classified as polymer electrolytes, have been developed and characterized in recent years. Special interest today is focused on composite gel polymer electrolyte systems having high ionic conductivity at ambient temperatures, since they may find unique applications, for example in rechargeable lithium batteries, separators, and fuel cells. Polyacrylonitrile (PAN) [1], poly (vinylidene fluoride) (PVDF) [2-4], poly(vinylidene fluoride-co-hexafluoropropylene) (PVDF-HFP) $[5,6]$ and poly(methyl methacrylate) (PMMA) [7-9] are the most common host polymers used for preparing gel electrolytes. Ceramic fillers such as $\mathrm{SiO}_{2}$ [10], $\mathrm{Al}_{2} \mathrm{O}_{3}$ [11], $\mathrm{TiO}_{2}$ [12] and $\mathrm{BaTiO}_{3}$ [13] have been incorporated along with the host polymer in order to obtain composite polymer electrolytes with improved electrical and mechanical properties. The ceramic fillers can promote electrochemical properties, but only by physical action without directly contributing to the lithium ion transport process. By suitable surface modification of the ceramic particles, they can also act as the source of charge $[14,15]$.

These considerations motivated us to modify the polymer matrix by introducing inorganic materials containing dissociative lithium ions. In this study, CMGPE based on PVDF which was doped with $\mathrm{SiO}_{2}\left(\mathrm{Li}^{+}\right)$were prepared and characterized.

\section{Experimental}

\subsection{Materials}

PVDF homopolymer $\left(\mathrm{M}_{\mathrm{n}}\right.$, ca. $1.66 \times 10^{5} ; \mathrm{M}_{\mathrm{w}}$, ca. $3.31 \times$ $105 ; \mathrm{M}_{\mathrm{w}} / \mathrm{M}_{\mathrm{n}}=1.99$, Shanghai Ofluorine Chemical) was 
used as polymer matrix and Tetraethylorthosilicate (TEOS,Sinopharm Chemical Reagent Co., Ltd) $\gamma-(2$, 3-epoxypropoxy) propyltrimethoxysilane (KH560, GuotaiHuarong Chemical) were employed to provide silica source. $\mathrm{LiOH} \cdot \mathrm{H}_{2} \mathrm{O}$ (Sinopharm Chemical) was used as received without further purification. Organic liquid electrolyte (EC/EMC/DMC 1:1:1(W/W/W) $\mathrm{LiPF}_{6} 1 \mathrm{~mol} / \mathrm{l}$, GuotaiHuarong Chemical).

\subsection{Synthesis of $\mathrm{SiO}_{2}\left(\mathrm{Li}^{+}\right)$}

TEOS and KH560 were dissolved in ethanol at mol rate of $2: 1$, a little of concentrated hydrochloric acid solution (36 $\mathrm{wt} \%$ ) was added into the obtained solution to adjust its $\mathrm{pH}$ to about 2.0. The mixture were heated to $75{ }^{\circ} \mathrm{C}$ with magnetic force stirring for $6 \mathrm{~h}$ to get the silica $\mathrm{SiO}_{2}$, then calculated amounts of standard solutions of the lithium hydroxide in methanol were added. The reaction last for about $2 \mathrm{~h}$ until silica $\mathrm{SiO}_{2}\left(\mathrm{Li}^{+}\right)$were prepared. And the white powder $\mathrm{SiO}_{2}\left(\mathrm{Li}^{+}\right)$can be obtained after being dried under vacuum at $100{ }^{\circ} \mathrm{C}$ for $24 \mathrm{~h}$.

\subsection{Preparation of Composite Microporous Gel Polymer Electrolyte}

The CMGPEs doped with $\mathrm{SiO}_{2}\left(\mathrm{Li}^{+}\right)$were fabricated by standard solution-casting technique coupled with traditional phase inversion method. A proper amount of PVDF was first dissolved in the solvent ( $N, N$-dimethylformamide, DMF), it was stirred for about $18 \mathrm{~h}$ at room temperature. Then, a proper amount of $\mathrm{SiO}_{2}\left(\mathrm{Li}^{+}\right)$were added into the polymer solution and the solution were stirred for other $6 \mathrm{~h}$ to make them dissolved completely. The relative weight ratio of $\mathrm{SiO}_{2}\left(\mathrm{Li}^{+}\right)$to PVDF was varied from 1 to $10 \mathrm{wt} \%$. The polymer solution was cast on a glass with a stainless steel blade in a thickness of $\sim 150 \mu \mathrm{m}$, then it was put into methanol for $45 \mathrm{~s}$, and then dried in the vacuum oven at $100{ }^{\circ} \mathrm{C}$ for $24 \mathrm{~h}$. To get the CMGPEs, the prepared membranes were transferred to the glove box and immersed in the organic liquid electrolyte. After activation, the membranes were removed from the liquid electrolyte and excess electrolyte solution on the surface was wiped with a filter paper. For convenience, different samples obtained from different relative concentration of $\mathrm{SiO}_{2}\left(\mathrm{Li}^{+}\right)$ to PVDF were denoted as PVDF-X $\% \mathrm{SiO}_{2}\left(\mathrm{Li}^{+}\right)$.

\subsection{Measurements}

FT-IR measurements were carried out on BRUKER VECTOR-22 spectrometer at room temperature. The spectra were collected over the range $400-4,000 \mathrm{~cm}^{-1}$ by averaging 128 scans at a maximum resolution of $2 \mathrm{~cm}^{-1}$.
DSC measurements were carried out using a DSC Q100 (TA Instruments) (TA Instruments, USA) over a temperature of $20-200{ }^{\circ} \mathrm{C}$ at a scan rate of $10{ }^{\circ} \mathrm{C} / \mathrm{min}$. All the thermograms were base line corrected and calibrated using Indium metal. The experimental specimens (8-10 mg) were dried at $60^{\circ} \mathrm{C}$ under vacuum for $24 \mathrm{~h}$ before being measured. All the samples were firstly annealed at $120^{\circ} \mathrm{C}$ for $3 \mathrm{~min}$, cooled to $20^{\circ} \mathrm{C}$ using liquid nitrogen and then scanned for the measurement.

$\mathrm{X}$-ray diffractions analysis of the polymer films were performed using a D/MAX-RA X-ray diffractometer (Rigaku) with $2 \theta$ values between $3^{\circ}$ and $60^{\circ}$.

Morphology of the composite polymer membranes were observed by scanning electron microscopy (SEM) (XL30-ESEM, PHILIPS) under vacuum.

Tensile properties of the composite polymer membranes were measured through a $10 \mathrm{KN}$ electromechanical tensile testing machine (CMT5104, China) at room temperature. The tensile speed was $40 \mathrm{~mm} / \mathrm{min}$.

The porosity $(P)$ of CPE membranes can be calculated by Eq. (1) after the membranes were immersed into $n$-butanol for $30 \mathrm{~min}$, where $\rho_{\mathrm{a}}$ and $\rho_{\mathrm{b}}$ are the density of $n$-butanol and the dry CPE membrane, respectively; $\mathrm{m}_{\mathrm{a}}$ and $\mathrm{m}_{\mathrm{b}}$ are the mass of the membrane with $n$-butanol and the dry membrane, respectively.

$P=\frac{\mathrm{m}_{\mathrm{a}} / \rho_{\mathrm{a}}}{\left(\mathrm{m}_{\mathrm{a}} / \rho_{\mathrm{b}}\right)+\mathrm{m}_{\mathrm{b}} / \rho_{\mathrm{b}}}$

Swelling behavior of the CMGPEs were processed in a dry glove box. The film samples were first cut into a specimen of $2 \mathrm{~cm}$ in diameter. After the mass was weighted, they were immersed in the liquid electrolyte. The CPEs were taken out at different times until no weight changed. The swelling capability of electrolyte solution contents was determined as follows: $\mathrm{S}_{\mathrm{w}}=100\left(\mathrm{~W}-\mathrm{W}_{0}\right) / \mathrm{W}_{0}$, where $\mathrm{W}_{0}$ and $\mathrm{W}$ were weights of the initial and wet films.

The ionic conductivity $(\sigma)$ of the CMGPEs were determined by AC impedance spectroscopy (EG\&G Model 273A potentiostat). It was sandwiched between two parallel stainless steel (SUS) discs (Ф: $1 \mathrm{~cm}$ ) and mounted in a sealed coin cell to prevent contamination of the sample. The frequency ranged from $100 \mathrm{kHz}$ to $10 \mathrm{~Hz}$ at a perturbation voltage of $5 \mathrm{mV}$. The ionic conductivity $(\sigma)$ was then calculated from the electrolyte resistance $\left(R_{b}\right)$ obtained from the intercept of the Nyquist plot with the real axis, the membrane thickness(l), and the electrode area(A) according to the equation $\sigma=1 / \mathrm{AR}_{\mathrm{b}}$.

The electrochemical stability window of the semi-IPN gel polymer electrolyte was measured by linear sweep voltammetry (LSV) at a scanning rate of $0.05 \mathrm{~V} / \mathrm{s}$. Three electrode-laminated cell was assembled inside a glove box. Stainless steel (SS) was used as working electrode and lithium metal was used both as a counter and as a reference 
electrode. LSV measurement was carried out using CHI660A (CH Instruments. Inc).

\section{Results and Discussion}

\subsection{FT-IR Spectrum Measurements}

Figure 1 shows the FT-IR spectrum for $\mathrm{SiO}_{2}\left(\mathrm{Li}^{+}\right)$. The characteristic absorption peaks $3,440 \mathrm{~cm}^{-1}\left(\mathrm{v}_{\mathrm{Si}-\mathrm{OH}}\right)$, $2,940 \mathrm{~cm}^{-1}\left(v_{\mathrm{C}-\mathrm{H}}\right), 1,060 \mathrm{~cm}^{-1}\left(\delta_{\mathrm{as}, \mathrm{Si}-\mathrm{O}-\mathrm{Si}}\right)$, and $1,785 \mathrm{~cm}^{-1}$ $\left(v_{\mathrm{C}=\mathrm{O}}\right)$ are observed in IR spectrum, and the disappearance absorption peaks of $950-815 \mathrm{~cm}^{-1}$ for epoxy bond means that $\mathrm{LiOH}$ have reacted with the modified $\mathrm{SiO}_{2}$ and $\mathrm{SiO}_{2}\left(\mathrm{Li}^{+}\right)$were prepared according to above reaction.

Figure 2 shows the characteristic FT-IR spectra for PVDF and PVDF-5 $\% \mathrm{SiO}_{2}\left(\mathrm{Li}^{+}\right)$respectively. $\alpha$ - and $\gamma$-phases of PVDF characterizing bands are observed in the range of $400-1,600 \mathrm{~cm}^{-1}$. The assignment of FT-IR spectra of the samples have reported as follows: $\alpha$-phase $\left(\mathrm{TGTG}^{-}\right) ; 472$ and $509 \mathrm{~cm}^{-1}$ ( $\mathrm{CF}_{2}$ bending), $1,070 \mathrm{~cm}^{-1}\left(\mathrm{CH}_{2}\right.$ wagging) and $\gamma$-phase $\left(\right.$ TTTGTTTG $\left.^{-}\right) ; 841 \mathrm{~cm}^{-1}$ (CH out-of-plane deformation and $\mathrm{CH}_{2}$ rocking), $881 \mathrm{~cm}^{-1}\left(\mathrm{CF}_{2}\right.$ symmetric stretching), $1,280 \mathrm{~cm}^{-1}$ (CF out-of-plane deformation), $1,400 \mathrm{~cm}^{-1}\left(\mathrm{CH}_{2}\right.$ wagging $)$ [16]. The enhancement of the intensity of absorption peak in the range of 1,280$1,070 \mathrm{~cm}^{-1}$ means that the $\mathrm{SiO}_{2}\left(\mathrm{Li}^{+}\right)$is added into the composite polymer membrane. However, with the addition of $\mathrm{SiO}_{2}\left(\mathrm{Li}^{+}\right)$, no visible shifting for PVDF characterizing bonds are observed.

\subsection{DSC Measurements}

Figure 3 displays the typical DSC thermograms obtained for composite polymer membranes varied with the content of $\mathrm{SiO}_{2}\left(\mathrm{Li}^{+}\right)$, and their dynamic data are listed in the Table 1 .

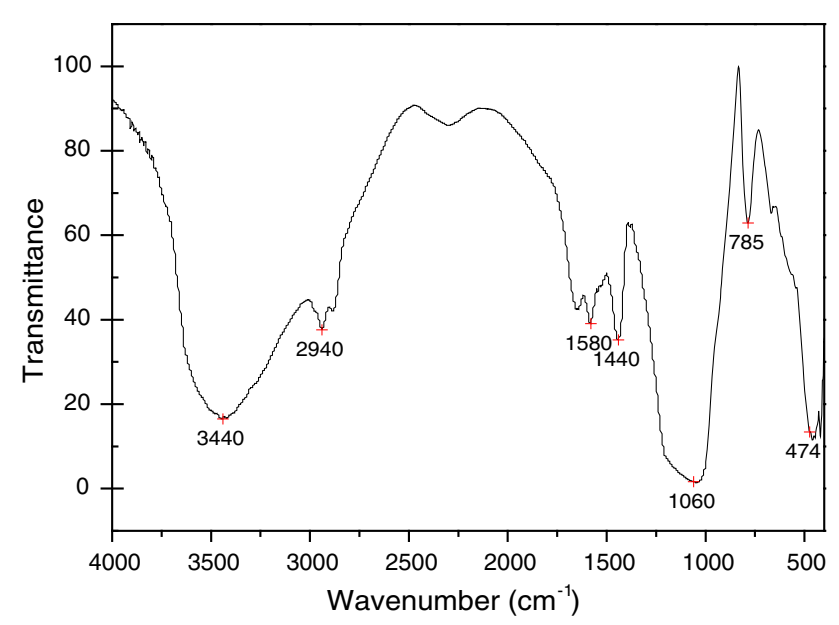

Fig. 1 FT-IR spectrum for $\mathrm{SiO}_{2}\left(\mathrm{Li}^{+}\right)$
It is found that there is a crystal melting peak from 150 to $170{ }^{\circ} \mathrm{C}$ which is attributed to partly crystallinity of the PVDF. With the content of $\mathrm{SiO}_{2}\left(\mathrm{Li}^{+}\right)$increases, the crystalline melting temperature $\left(\mathrm{T}_{\mathrm{m}}\right)$ and crystallinity for the composite polymer membranes are both decreased. The result suggests that the polymer chains may be hindered by the cross-linking centers formed by the interaction of the Lewis acid groups ceramics (e.g. the $-\mathrm{OLi}$ groups and $-\mathrm{OH}$ on the $\mathrm{SiO}_{2}\left(\mathrm{Li}^{+}\right)$) with the polar groups (e.g. the $-\mathrm{F}$ groups of the polymer chains). So, the degree of crystallization of polymer matrix decreases with addition of $\mathrm{SiO}_{2}\left(\mathrm{Li}^{+}\right)$. The added Silicas are far more receptive to the segmental chain motion of the polymer [17]. Such an interaction stabilizes the amorphous structure and enhances the ionic conductivity of CMGPEs [18].

\subsection{TGA Measurement}

Figure 4 shows the TGA results for pure PVDF membrane and composite polymer membrane (PVDF-5\% $\% \mathrm{SiO}_{2}\left(\mathrm{Li}^{+}\right)$) respectively. No significant weight loss are observed until $430{ }^{\circ} \mathrm{C}$ for the composite polymer membrane. It can improve the heat resistant of PVDF based composite polymer membrane by addition of $\mathrm{SiO}_{2}\left(\mathrm{Li}^{+}\right)$. It is very interesting that amount of residue of PVDF membrane is higher than the composite membrane when the temperature exceed $500{ }^{\circ} \mathrm{C}$. $\mathrm{SiO}_{2}\left(\mathrm{Li}^{+}\right)$is prepared by sol-gel reaction of TEOS and KH560, which has a few organic groups in the Silica. The decomposed organic groups after thermal decomposition of platforms may cause this phenomenon.

\subsection{XRD Measurements}

The X-ray diffraction patterns of composite polymer membrane varied with the content of $\mathrm{SiO}_{2}\left(\mathrm{Li}^{+}\right)$are presented in

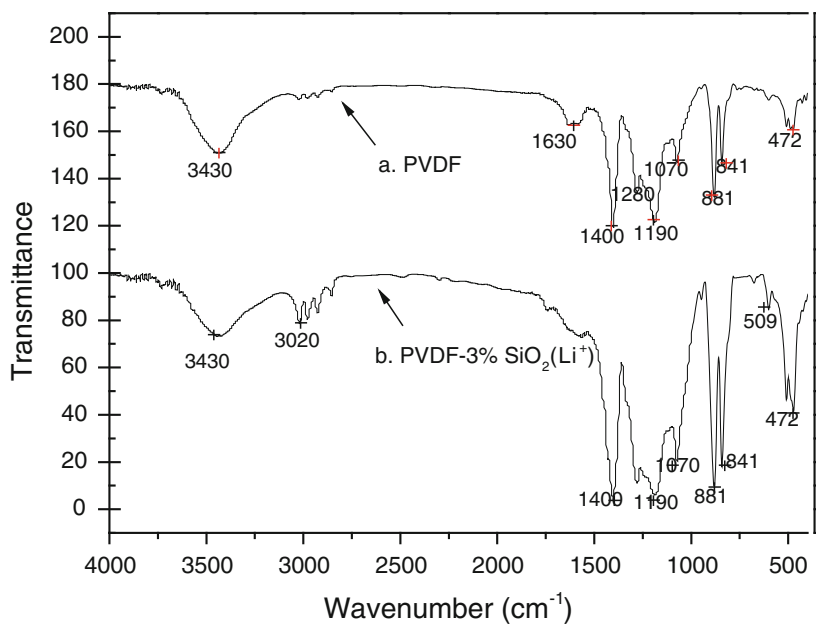

Fig. 2 FT-IR spectra of a pure PVDF, b PVDF-5 \% $\mathrm{SiO}_{2}\left(\mathrm{Li}^{+}\right)$ 


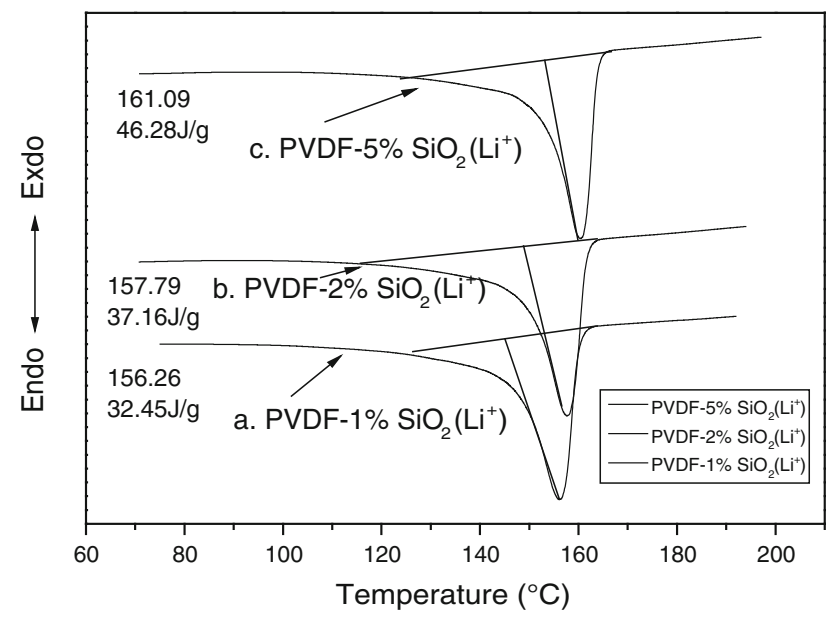

Fig. 3 DSC curves for composite membranes a PVDF-1 $\% \mathrm{SiO}_{2}\left(\mathrm{Li}^{+}\right)$, b PVDF-2 \% $\mathrm{SiO}_{2}\left(\mathrm{Li}^{+}\right)$, c PVDF-5 $\% \mathrm{SiO}_{2}\left(\mathrm{Li}^{+}\right)$

Table 1 Properties of PVDF and the cross-linked copolymer coated PVDF

\begin{tabular}{|c|c|c|c|}
\hline Sample & $\mathrm{T}_{\mathrm{m}}\left({ }^{\circ} \mathrm{C}\right)$ & $\Delta \mathrm{H}_{\mathrm{m}}(\mathrm{J} / \mathrm{g})$ & $\chi(\%)$ \\
\hline PVDF-5 $\% \mathrm{SiO}_{2}\left(\mathrm{Li}^{+}\right)$ & 156.26 & 32.45 & 30.99 \\
\hline PVDF-2 $\% \mathrm{SiO}_{2}\left(\mathrm{Li}^{+}\right)$ & 157.79 & 37.16 & 35.49 \\
\hline PVDF-1 $\% \mathrm{SiO}_{2}\left(\mathrm{Li}^{+}\right)$ & 161.09 & 46.28 & 44.20 \\
\hline
\end{tabular}

a degree of crystallization

Fig. 2. It shows that the relative intensity of the broad diffraction peak at Brag angle of $2 \theta=20.50^{\circ}$ decreases with increasing of the concentration of $\mathrm{SiO}_{2}\left(\mathrm{Li}^{+}\right)$, which suggests that the added $\mathrm{SiO}_{2}\left(\mathrm{Li}^{+}\right)$can lower the crystallinity of the polymer membrane. Moreover, the XRD pattern shows broader and fewer peaks after adding $\mathrm{SiO}_{2}\left(\mathrm{Li}^{+}\right)$into polymer matrix, which suggests that the CPE membrane may possess more amorphous areas for lithium-ion transfer. The

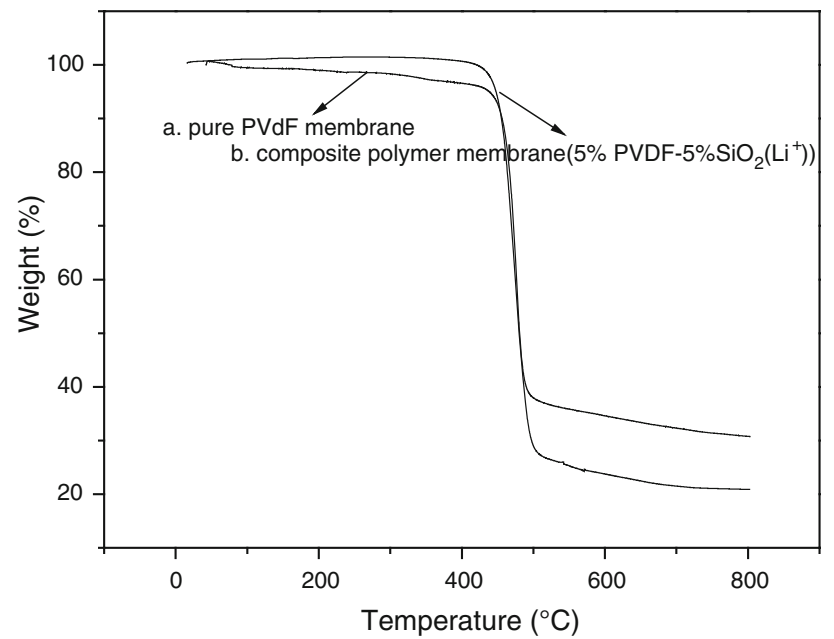

Fig. 4 Thermograms of polymer membranes a pure PVDF, b PVDF-5 $\% \mathrm{SiO}_{2}\left(\mathrm{Li}^{+}\right)$

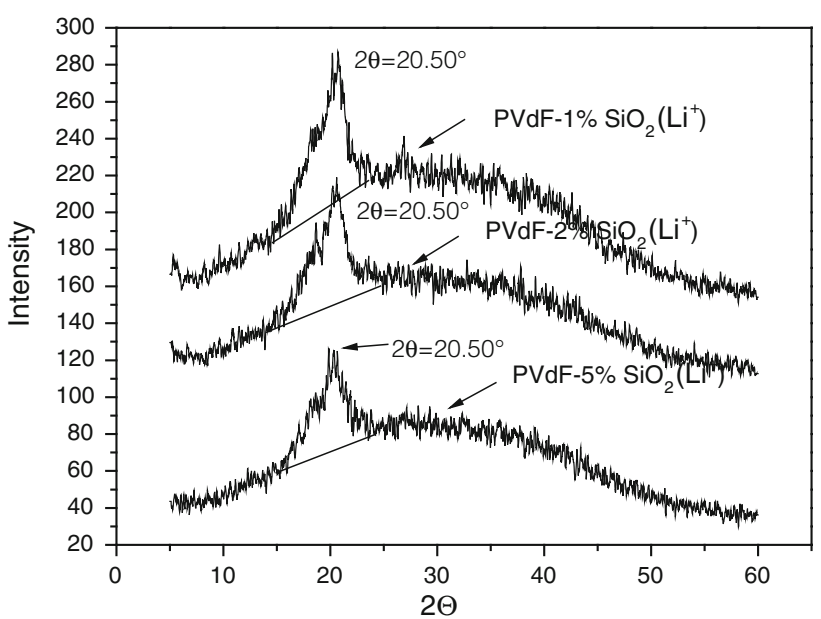

Fig. 5 XRD patterns for PVDF based composite polymer membrane varied with different content of $\mathrm{SiO}_{2}\left(\mathrm{Li}^{+}\right)$

interaction of PVDF chains between $\mathrm{SiO}_{2}\left(\mathrm{Li}^{+}\right)$may lead to lower crystallinity and rich amorphous phase for the composite polymer membrane. This result can be interpreted by considering the Hodge et al. [19] criterion which establishes a correlation between the height of the peak and the degree of crystallinity. In addition, no characteristic peak of $\mathrm{SiO}_{2}\left(\mathrm{Li}^{+}\right)$ is found confirms that the particles is successfully encapsulated by polymer membranes. Thus, the X-ray study reveals the complex formation in the composite polymer membrane and the result is consistent with DSC result.(Fig. 5)

\subsection{SEM Measurements}

Figure 6a-f show the microphotographs of composite polymer membranes varied with the content of $\mathrm{SiO} 2\left(\mathrm{Li}^{+}\right)$ to PVDF. It can be found that the pore size of the membrane increased with the content of the $\mathrm{SiO}_{2}\left(\mathrm{Li}^{+}\right)$. It might be caused by a portion of $\mathrm{SiO}_{2}\left(\mathrm{Li}^{+}\right)$dispersed in the methanol when the membrane was immersed in the solution. Presence of microspores in the membrane leaded to efficient uptake of the liquid electrolyte when it was soaked in an electrolyte solution, and finally they benefit to the gelation of the microporous membrane [20]. However, excess pores in the membrane could deteriorate the mechanical properties of the gel polymer electrolyte. When the content of the $\mathrm{SiO}_{2}\left(\mathrm{Li}^{+}\right)$reached $10 \%$, the prepared gel polymer electrolyte was very fragile which could not be handled by hand.

\subsection{Porosity and Swelling Measurements}

It can be seen from Table 2 that the porosity of pure microporous PVDF membrane is $31.65 \%$, and equilibrium swelling ratio $S_{w}$ is 287.32. From the result of SEM and porosity measurement, the pore size and porosity of the 
Fig. 6 Scanning electron micrograph images of surface of the composite polymer membranes: a pure PVDF, b PVDF-1 $\% \mathrm{SiO}_{2}\left(\mathrm{Li}^{+}\right)$, c PVDF-2 $\% \mathrm{SiO}_{2}\left(\mathrm{Li}^{+}\right)$, d PVDF-5 \% $\mathrm{SiO}_{2}\left(\mathrm{Li}^{+}\right)$, e PVDF- $10 \% \mathrm{SiO}_{2}\left(\mathrm{Li}^{+}\right)$
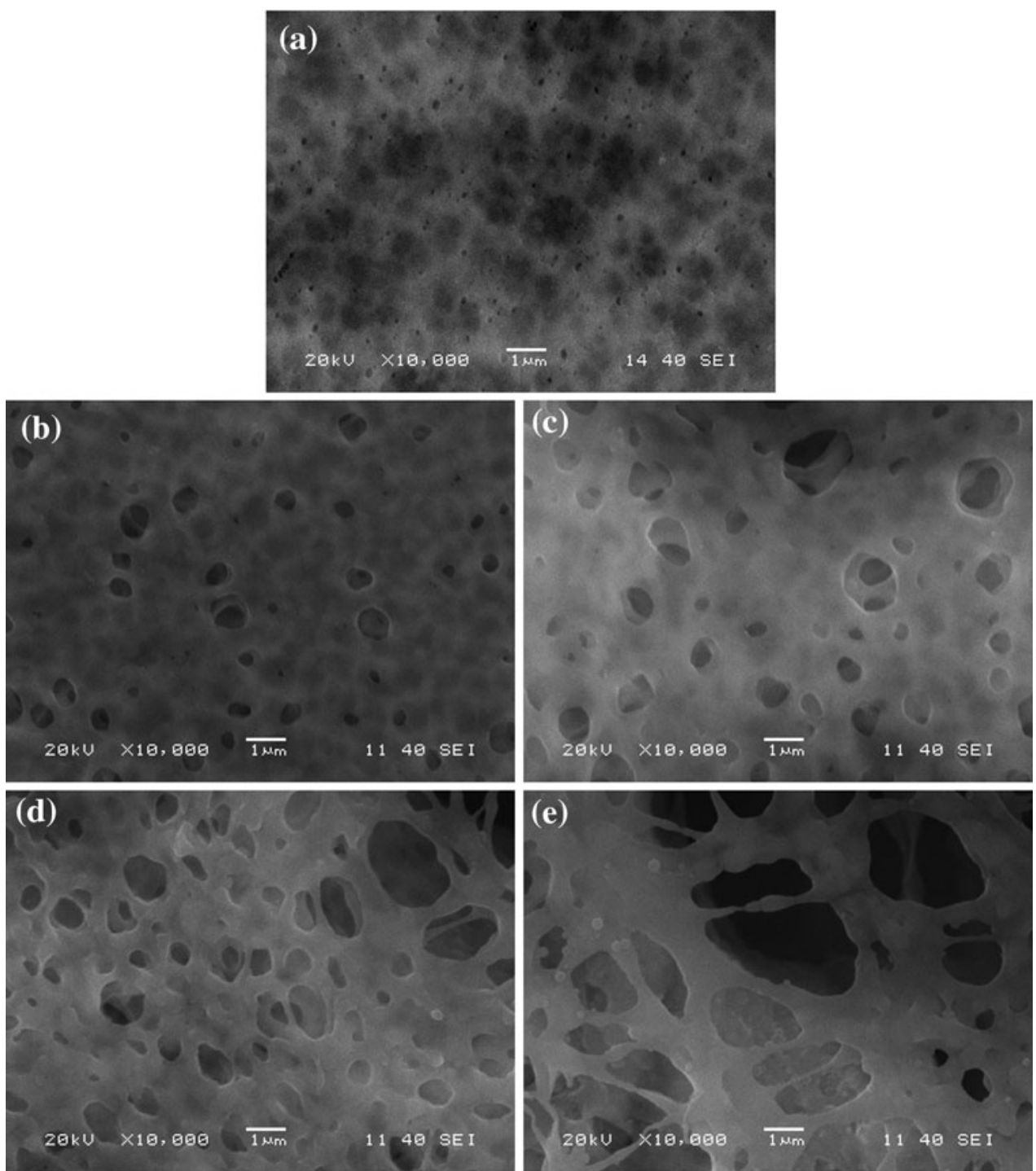

Table 2 Physical properties and ionic conductivity of CMGPEs

\begin{tabular}{|c|c|c|c|}
\hline Polymer membranes & Porosity (\%) & $\mathrm{S}_{\mathrm{w}}(\%)$ & $\begin{array}{l}\text { Ionic conductivity } \\
(\mathrm{S} / \mathrm{cm})\end{array}$ \\
\hline Pure PVDF & 31.65 & 287.32 & $6.2 \times 10^{-3}$ \\
\hline PVDF-1 $\% \mathrm{SiO}_{2}\left(\mathrm{Li}^{+}\right)$ & 38.76 & 318.27 & $3.76 \times 10^{-2}$ \\
\hline PVDF-2 $\% \mathrm{SiO}_{2}\left(\mathrm{Li}^{+}\right)$ & 50.23 & 359.77 & $3.81 \times 10^{-2}$ \\
\hline PVDF-5 $\% \mathrm{SiO}_{2}\left(\mathrm{Li}^{+}\right)$ & 51.08 & 362.45 & $3.87 \times 10^{-2}$ \\
\hline
\end{tabular}

composite polymer membrane are both increased with the content of the $\mathrm{SiO}_{2}\left(\mathrm{Li}^{+}\right)$, which can make the liquid electrolyte be absorbed and gelification easily, and lead to the higher ionic conductivity in the end. When the content of $\mathrm{SiO}_{2}\left(\mathrm{Li}^{+}\right)$is $5 \%$, the porosity of the composite polymer membrane and the $S_{w}$ are 51.08 and 362.45 respectively, and the ionic conductivity at room temperature reaches $3.83 \times 10^{-2} \mathrm{~S} / \mathrm{cm}$.

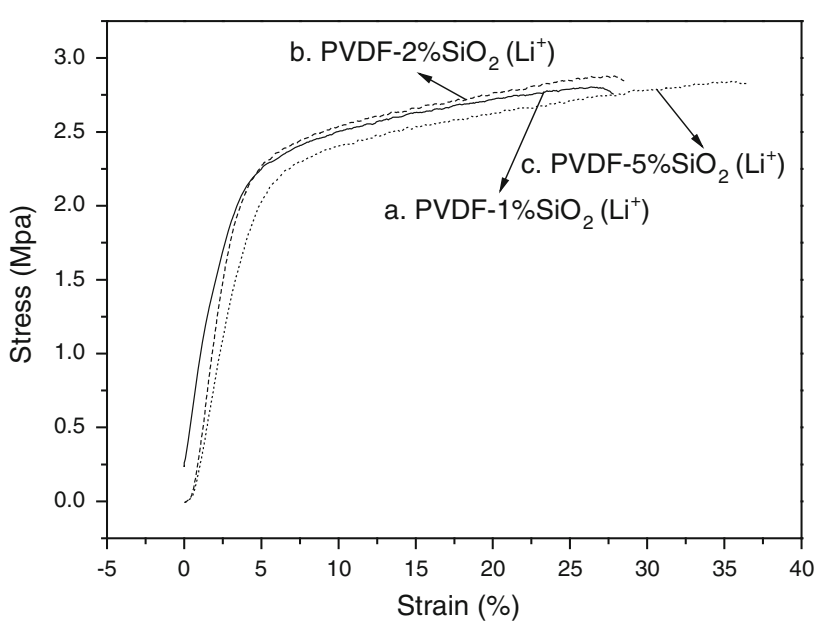

Fig. 7 Stress-strain curves of the composite membranes a PVDF$1 \% \mathrm{SiO}_{2}\left(\mathrm{Li}^{+}\right)$, b PVDF-2 $\% \mathrm{SiO}_{2}\left(\mathrm{Li}^{+}\right)$and c PVDF-5 $\% \mathrm{SiO}_{2}\left(\mathrm{Li}^{+}\right)$ 
(a)

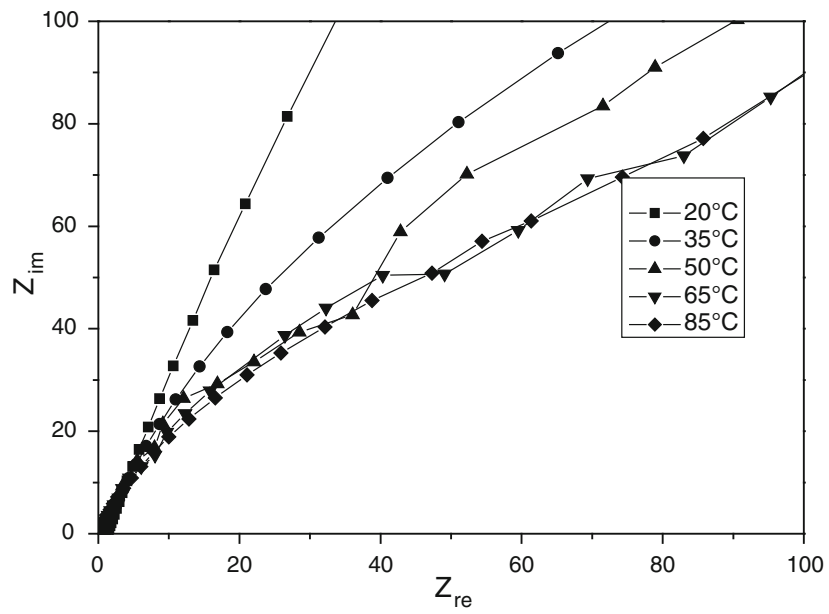

(b)

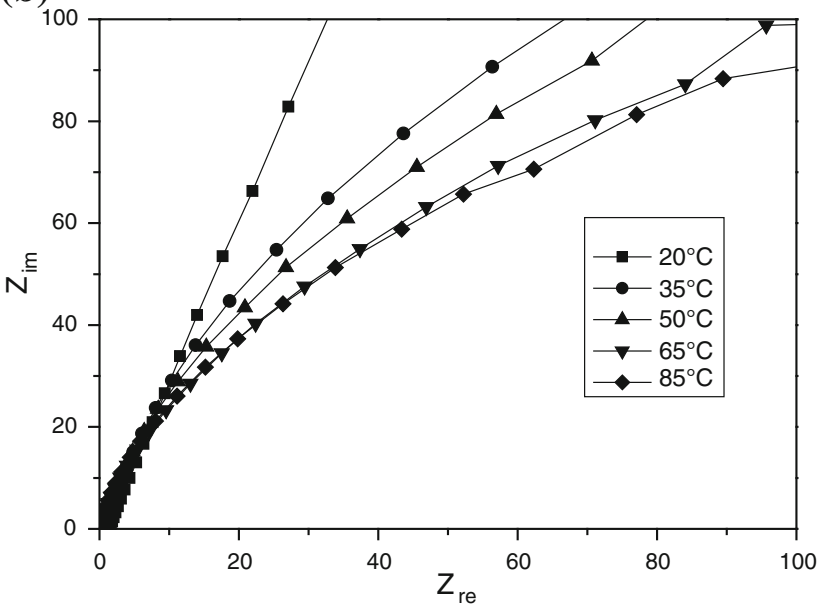

(c)

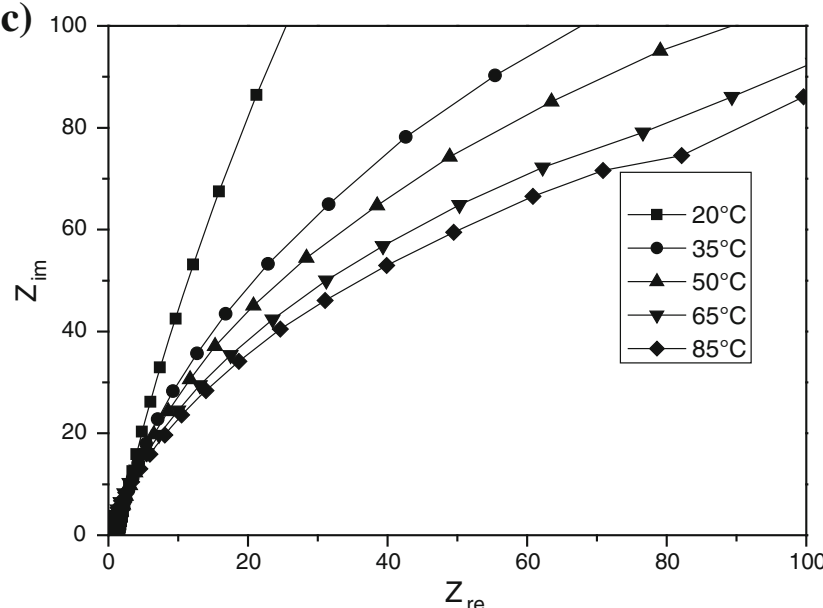

Fig. 8 AC impedance spectra of composite gel electrolyte membrane in different temperature: a PVDF- $1 \% \mathrm{SiO}_{2}\left(\mathrm{Li}^{+}\right), \mathbf{b} \mathrm{PVDF}^{2} \% \mathrm{SiO}_{2}\left(\mathrm{Li}^{+}\right)$ and $\mathbf{c}$ PVDF-5 $\% \mathrm{SiO}_{2}\left(\mathrm{Li}^{+}\right)$

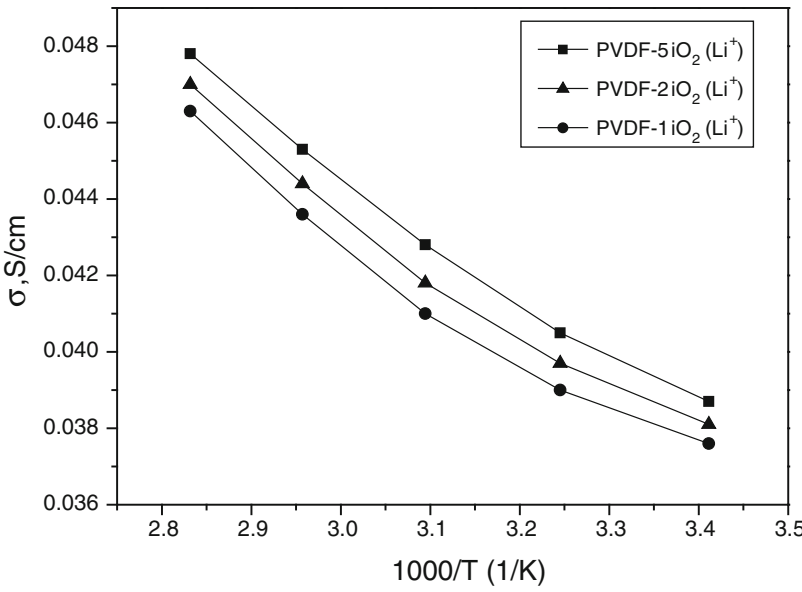

Fig. 9 Dependence of conductivity on the reciprocal of temperature for composite gel polymer electrolyte (wt \%)
Table 3 Mechanical properties of composite polymer membranes with different content of $\mathrm{SiO}_{2}\left(\mathrm{Li}^{+}\right)$

\begin{tabular}{lll}
\hline $\begin{array}{l}\text { Polymer } \\
\text { membranes }\end{array}$ & $\begin{array}{l}\text { Tensile } \\
\text { strength }(\mathrm{Mpa})\end{array}$ & $\begin{array}{l}\text { Elongation at } \\
\text { break }(\%)\end{array}$ \\
\hline PVDF-1 \% $\mathrm{SiO}_{2}\left(\mathrm{Li}^{+}\right)$ & 2.80 & 27.793 \\
PVDF-2 $\% \mathrm{SiO}_{2}\left(\mathrm{Li}^{+}\right)$ & 2.89 & 28.498 \\
PVDF-5 $\% \mathrm{SiO}_{2}\left(\mathrm{Li}^{+}\right)$ & 2.85 & 36.332 \\
\hline
\end{tabular}

\subsection{Stress-Strain Response}

Figure 7 show typical engineering stress-strain behavior for the composite polymer membranes along the machine 
direction, and the results of the stress and strain for them are list in the Table 1. The elongation at break increases with increasing the content of $\mathrm{SiO}_{2}\left(\mathrm{Li}^{+}\right)$. With the character of small size and large surface, the $\mathrm{SiO}_{2}\left(\mathrm{Li}^{+}\right)$can contact with the polymer chains adequately, which can absorb the impact forces and prevent further expansion of the crack of the materials when the composite polymer membranes are be attacked. The results show that the composite gel polymer electrolyte can be applied in the polymer lithium-ion battery with the addition a proper amount of $\mathrm{SiO}_{2}\left(\mathrm{Li}^{+}\right)$.

\subsection{Ionic Conductivity Measurement}

Figure $8 \mathrm{a}-\mathrm{c}$ are the typical $\mathrm{AC}$ impedance spectra for composite gel polymer electrolyte varied with the content of $\mathrm{SiO}_{2}\left(\mathrm{Li}^{+}\right)$. No semicircle is observed at high frequency. The result suggests that only the resistive component of composite gel polymer electrolyte could be considered at the high amount of plasticizing electrolyte. It is possible to construct a local effective pathway in liquid phase and in gel phase for ionic conduction [21]. With the assistance of the lithium-ion in the $\mathrm{SiO}_{2}\left(\mathrm{Li}^{+}\right)$, the lithium salt in the composite gel polymer electrolyte could disassociate easily, and the ion mobility is decoupled with the segmental motion of the polymer chain, and it is transferred through gel electrolyte [22]. Lithium-ion can transport quickly in these phases as the electric potential alternates between positive electrode and negative electrode in an AC field.

The $\sigma$ vs. 1/T plots for the composite gel polymer electrolyte is shown in Fig. 9. It obviously shows that the ionic conductivity increases with the temperature. This behavior can be rationalized by recognizing the free-volume model $[15,23]$. As the temperature increases, it results in an increase in the overall mobility of the ions and polymer chains. The linear relationship suggests that the conductivity is thermally activated. The conductivity relationship can be expressed as.

$\sigma=A \exp \left(-E_{a} / R T\right)$

where $E_{a}$ is the activation energy, $A$ is a constant and $T$ is the absolute temperature. The corresponding of the activation energy of the electrolyte material means that the charge transport in the composite gel polymer electrolyte is independent of the segmental movements of the PVDF, and thus a 'fast' charge transport might occur in the composite gel polymer electrolyte in the temperature range $20-70{ }^{\circ} \mathrm{C}$.

It is well known that there are three phases in the composite gel polymer electrolyte: solid state PVDF polymer matrix, the gelled polymeric matrix coming from the swelling of organic components in non-aqueous electrolyte, and absorbed liquid electrolyte. The solid state polymer matrix ensures the mechanical strength of the gel polymer

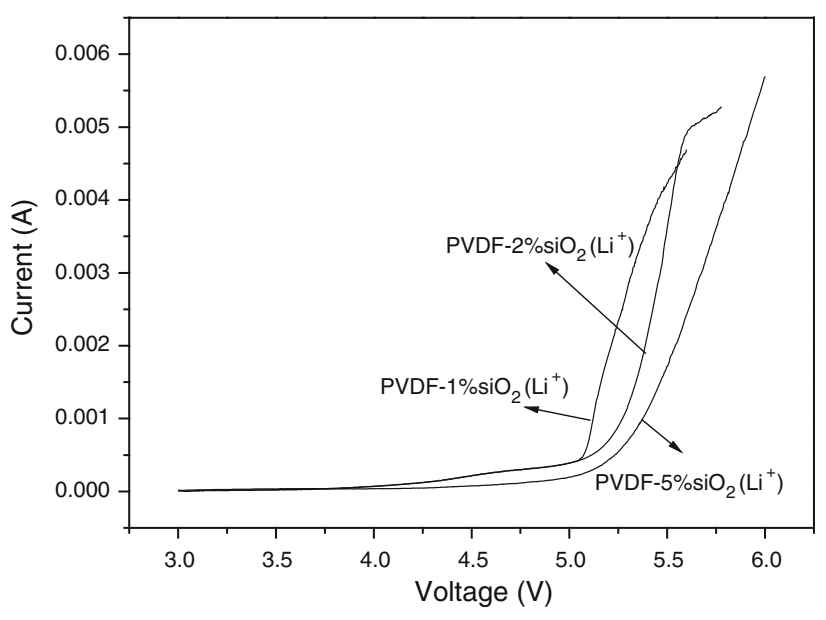

Fig. 10 Electrochemical stability window of CMGPEs varied with the addition of $\mathrm{SiO}_{2}\left(\mathrm{Li}^{+}\right)$

electrolyte, and the others provide a high ionic conductivity. In our case, there is a new phase, $\mathrm{SiO}_{2}\left(\mathrm{Li}^{+}\right)$, in the composite gel polymer electrolytes. The nano-particles influence, on one hand, the porous structure of the polymer membrane. On the other hand, Lewis acid-base effect, which comes from the interaction between -OLi groups on the surface of $\mathrm{SiO}_{2}\left(\mathrm{Li}^{+}\right)$and polar $\mathrm{CF}_{2}$ groups of polymer chains, can weaken the interaction the interaction between $\mathrm{Li}^{+}$ions and anions and facilitating their migration [24, 25]. However excess silica may destroy the mechanical properties of the composite gel polymer electrolyte. At $5 \mathrm{wt} \%$, the composite polymer membrane reaches to the highest porosity, so its apparent activation energy for ions transport is down to the minimum value and the ionic conductivity reaches to the highest value.(Table 3 )

\subsection{Electrochemistry Stability Measurements}

For a lithium-ion polymer battery, the cell potential can approach as high as $4.5 \mathrm{~V}$ versus $\mathrm{Li} / \mathrm{Li}^{+}$, implying that the composite polymer electrolyte should be electrochemically stable up to at least $4.5 \mathrm{~V}$ [25]. To ascertain the electrochemical stability of the CMGPE, linear sweep voltammogram of the laminated three electrode cells was performed at ambient temperature. The electrochemical stability of the samples are presented in Fig. 10. The working electrode potential of the cell was varied from 3.0 to $6.0 \mathrm{~V}$ (vs. $\mathrm{Li}$ ) at sweep rate of $0.05 \mathrm{~V} / \mathrm{s}$.

It is evident from the figure that there is no electrochemical reaction in the potential range $3.0-5.1 \mathrm{~V}$. The onset of current flow at $5.1 \mathrm{~V}$ is associated with the decomposition of the electrolyte. So the anodic stability limit of the electrolyte is $5.1 \mathrm{~V}$ versus that of $\mathrm{Li}$, which is sufficiently high for the lithium oxide cathodes $\mathrm{LiCoO}_{2}$ and $\mathrm{Li}_{2} \mathrm{Mn}_{2} \mathrm{O}_{4}$ [26]. Hence it may be concluded that the added 
$\mathrm{SiO}_{2}\left(\mathrm{Li}^{+}\right)$can improve the electrochemical stability of the CMGPEs due to its property of electrochemical inert.

\section{Conclusion}

A new type of composite gel polymer electrolyte varied with the content of $\mathrm{SiO}_{2}\left(\mathrm{Li}^{+}\right)$was prepared by immersion deposition technique. The crystallinity of the composite microporous polymer membrane decreases with the increase of the incorporated amount of $\mathrm{SiO}_{2}\left(\mathrm{Li}^{+}\right)$. While the Porosity and liquid electrolyte swelling ability increase with it, this is beneficial to absorb more liquid electrolytes. However, excessive $\mathrm{SiO}_{2}\left(\mathrm{Li}^{+}\right)$could destroy the mechanical properties of the microporous membrane. At the content of $5 \%$, the Sw of CMGPEs is 362.45 , and the ionic conductivity at room temperature could reach $3.87 \times 10^{-2} \mathrm{~S} / \mathrm{cm}$, and its electrochemical stability window is about $5.1 \mathrm{~V}$. The addition of the $\mathrm{SiO}_{2}\left(\mathrm{Li}^{+}\right)$can enhance the properties of the CMGPEs and make it potential candidate for application as polymer electrolyte in devices.

Acknowledgments This paper is supported by the "Undergraduate innovate programs of Jiangsu university of science and technology, 2012”.

Open Access This article is distributed under the terms of the Creative Commons Attribution License which permits any use, distribution, and reproduction in any medium, provided the original author(s) and the source are credited.

\section{References}

1. D. Peramunage, D.M. Pasquariello, K.M. Abraham, J. Electrochem. Soc. 142, 1789 (1995)

2. D. Saikia, A. Kumar, Electrochim. Acta 49, 2581 (2004)
3. H.P. Zhang, P. Zhang, Z.H. Li, M. Sun, Y.P. Wu, H.Q. Wu, Electrochem. Commun. 9, 1700 (2007)

4. P. Zhang, L.C. Yang, L. Li, Q.T. Qu, Y.P. Wu, J. Membr. Sci. 362, 113 (2010)

5. Z.H. Li, H.P. Zhang, P. Zhang, Y.P. Wu, X.D. Zhou, J. Power Sources 184, 562 (2008)

6. P. Zhang, G.C. Li, H.P. Zhang, L.C. Yang, Y.P. Wu, Electrochem. Commun. 11, 161 (2009)

7. O. Bohnke, G. Frand, M. Rezazzi, C. Rousselot, C. Truche, Sol. State Ionics 66, 97 (1993)

8. J. Vondrák, J. Reiter, J. Velická, B. Klápště, M. Sedlaříková, J. Dvořák, J. Power Sources 146(1-2), 436 (2005)

9. S.A. Agnihotry, P. Pradeep, S.S. Sekhon, Electrochim. Acta 44(18), 3121 (1999)

10. X. He, Q. Shi, X. Zhou, C. Wan, C. Jiang, Electrochim. Acta 51(6), 1069 (2005)

11. Y.W. Chen-Yang, H.C. Chen, F.J. Lin, C.W. Liao, T.L. Chen, Sol. State Ionics 156(3-4), 383 (2003)

12. C.W. Lin, C.L. Hung, M. Venkateswarlu, B.J. Hwang, J. Power Sources 146(1-2), 397 (2005)

13. T. Itoh, Y. Ichikawa, T. Uno, M. Kubo, O. Yamamoto, Sol. State Ionics 156(3-4), 393-399 (2003)

14. N.S. Choi, Y.M. Lee, B.H. Lee, J.A. Lee, J.K. Park, Sol. State Ionics 167, 293 (2004)

15. J. Sun, P. Bayley, D.R. MacFarlane, M. Forsyth, Electrochim. Acta 52, 7083 (2007)

16. I.S. Elashmawi, Mater. Chem. Phys. 107, 96 (2008)

17. D. Saikia, Y.W. Chen-Yang, Y.T. Chen, Y.K. Li, S.I. Lin, Desalination 234, 24 (2008)

18. A. Subramania, N.T. Kalyana Sundaram, A.R. Sathiya Priya, G. Vijaya Kumar, J. Membr. Sci. 294, 8 (2007)

19. R.M. Hodge, G.H. Edward, G.P. Simon, Polymer 37, 1371 (1996)

20. M. Yang, W. Li, G.G. Wang, J.Q. Zhang, Sol. State Ionics 176, 2829 (2005)

21. M. Matsumoto, T. Ichino, J.S. Rutt, S. Nishi, J. Electrochem. Soc. 141, 1989 (1994)

22. W.H. Meyer, Adv. Mater. 10, 439 (1998)

23. W.H. Hou, C.Y. Chen, Electrochim. Acta 49, 2105 (2004)

24. Y.-S. Lee, S.H. Ju, J.-H. Kim, S.S. Hwang, J.-M. Choi, Y.-K. Sun, H. Kim, B. Scrosati, D.-W. Kim, Electrochem. Commun. 17, 18 (2012)

25. M. Digar, S.-L. Hung, T.-C. Wen, J. Appl. Polym. Sci. 80, 1319 (2001)

26. A.K.M. Akther Hossain, H. Tabata, T. Kawai, J. Magn. Magn. Mater. 320, 1157 (2008) 